\title{
EDITORIAL EDITORAÇÃO, CULTURA CIENTÍFICA NO BRASIL E OS 20 ANOS DA EJJL
}

Temos lido sobre ataques às universidades e à produção intelectual universitária. Gente frustrada e/ou mal-intencionada, usando aquele argumento desinformado de que as universidades produzem coisas que ninguém lê.

Para eles é preciso dizer o seguinte: uma parte da produção intelectual acadêmica é escrita com a finalidade exclusiva de o sistema acadêmico avaliar competências de autores que, em geral, são candidatos a um grau acadêmico. É o caso das dissertações e dos trabalhos de conclusão de cursos de graduação. Há exceções, sempre bem-vindas. Mas são exceções.

Nenhum estudante, portanto, deveria sentir-se menosprezado se apenas sua orientadora e sua banca de avaliação prestarem atenção ao seu trabalho final de curso (de graduação ou de mestrado). Mesmo no caso das teses de doutorado, a regra é, exatamente, essa: pouca gente lerá esses trabalhos. E não há nada de errado nisso. Os leitores são avaliadores de competências para realizar esse tipo de produção intelectual. Por isso, tais trabalhos são requisitos de aprovação de graus acadêmicos.

No caso de livros, de teses de doutorado publicadas e também de papers publicados em periódicos científicos, é um pouco diferente: espera-se inovação no campo especializado do conhecimento. Esses trabalhos, em regra, serão lidos por um público mais abrangente, consumidor de ciência. Mesmo assim, é um público restrito de pesquisadores e interessados. Mas a leitura desses trabalhos não é imediata. Essa história de que um paper, uma tese ou um livro, tão logo é escrito, deve ser imediatamente lido e citado é desinformação. Em todas as áreas do conhecimento, isso só ocorre com as publicações de autores já consagrados pela crítica. Gente muito importante, figuras que o público especializado - e até o público em geral em alguns poucos casos - já elegeu como referência. Em geral, são trabalhos esperados e, por isso, são rapidamente lidos depois de publicados.

Relatórios e estudos sobre fator de impacto mostram que papers publicados em periódicos científicos são lidos por um público abrangente. Mas não do dia para a noite. Isso ocorre, em regra, com grande diluição de tempo e espaço. Alguns excelentes trabalhos são lidos apenas por estudiosos do mesmo tema. Muitos deles, porém, foram escritos com essa intenção. Os autores nunca tiveram a expectativa de que fossem lidos por um grande público. Esses casos funcionam como poesia. $\bigcirc$ Mário Quintana até dizia que essa era uma vantagem da poesia: a de ser escrita por e para leitores de poesia.

Quem puder ler a biografia de ganhadores do Prêmio Nobel nas áreas tradicionais da ciência - ou mesmo na literatura - vai se surpreender com os relatos. "Meus trabalhos iniciais publicados em periódicos, e alguns dentre os mais importantes, foram lidos por pouca gente." Essa frase é mais comum na biografia de grandes nomes da ciência do que podem imaginar obscurantistas de plantão. 
Bom seria se a geração de impacto fosse o principal desafio de um periódico de ciência, como é a EJJL. Gerar impacto é uma coisa que leva tempo, mas acontece quando o periódico ganha reputação e visibilidade. Exatamente o que vem acontecendo com a EJJL: cada vez mais autores com trabalhos inovadores procuram o periódico. E cada vez mais aumenta o público leitor.

Os desafios para um periódico como a EJJL, de uma área sem tradição forte de ciência, num país com centenas e centenas de periódicos para a mesma área (o direito), são muito especiais. Particularmente porque a ciência e a produção intelectual acadêmica têm novos desafios, além desses já conhecidos.

Como sabemos, a vida anda anormal. As coisas parecem meio desparafusadas. As coisas na vida pública balançaram muito desde a grande crise de 2008, a eleição de Donald Trump em 2016 e o Brexit, no mesmo ano de 2016; e, no Brasil, desde a Lava-Jato e o Impeachment presidencial. Ontem, no Brasil, éramos um país democrático, de cristãos, simpáticos com o mundo, e que desenvolveria ciência como aliada da solução dos problemas nacionais. Depois viramos um país de ódios, de pecadores e ousamos ameaçar a democracia e os resultados da ciência. A política nacional de ciência e de educação está em crise: tanto de financiamento quanto de rumos. O que devem fazer as universidades brasileiras para o futuro do Brasile É uma pergunta sem resposta clara.

Com relação à ciência, vimos o surgimento da "pós-verdade", do "negacionismo", das "redes sociais" como fonte de informação segura. Que a vida, vista assim, anda anormal não é novidade. Nem é coisa exclusiva de brasileiros. O que impressiona é que o valor da vida anda balançando também. Pensando bem, diria até que é o valor da morte que anda balançando. Antes era normal "morrer de raiva", "matar a fome", "morrer de amores". Depois, virou normal matar os outros. Bala na cara. Tráfico. Depois elegemos políticos que mostram "arminha" e que prometem "tiro na cabecinha". A vida anda anormal. Tão anormal que o novo normal é a morte da morte. É isso mesmo. A morte morreu. Em agosto de 2020, quando batemos 100.000 óbitos por Covid-19, eu pensei: a morte morreu. A morte não existe mais. É uma notícia. Não é triste, nem alegre. É só uma notícia no meio da tempestade de outras notícias. A morte morreu. Já não ensina nada. Não há rituais, nem choro, nem vela. É preciso enterrá-la.

É inegável que os obstáculos financeiros e ideológicos limitaram muito o papel da ciência em países desenvolvidos e que têm sistemas estruturados de ciência. Em países não desenvolvidos, como o Brasil e alguns outros da América Latina, com sistema de ciência semiestruturado, as coisas ficam bem mais difíceis. $O$ conjunto de dificuldades sobrepostas que se colocam para o desenvolvimento da pesquisa científica na área do direito, e para um periódico como a EJJL, não é pequeno. As adversidades são enormes. E parecem ter se avolumado nos últimos 10 anos.

E, no entanto, nesse período de adversidades sui generis:

a) completamos 20 anos de publicações ininterruptas;

b) alcançamos a melhor classificação possível pelos critérios da Capes - estrato A1; 
c) de 2013 a 2017, tivemos média de 30,6 mil visualizações por ano;

d) depois, entre meados de 2018 e meados de 2019, a média subiu para 66 mil visualizações por ano;

e) e em 2020, de 1 de janeiro a 6 de dezembro, a EJJL teve 102 mil visualizações;

f) também em 2020, criamos o laboratório de prática editorial para nossos estudantes de mestrado e doutorado.

Temos muito orgulho de nossos resultados. Mais ainda da liberdade acadêmica e do apoio institucional que nos é dado pela Reitoria e pelas Pró-reitorias da Unoesc. É o que nos permite conciliar espírito crítico, inovação, ensino e aprendizagem para desenvolver boa ciência.

Vamos adiante.

A EJJL, e também o Programa de Pós-graduação em Direito - cursos de Mestrado e Doutorado, foram forjados em dificuldades nada simples. Contudo, o aprendizado dos últimos 10 anos e o planejamento que temos para os próximos quatro nos fortalece. São as nossas melhores bússolas.

Agradeço o gentil convite do Editor-chefe da EJJL, Prof. Dr. Marco Aurélio Rodrigues da Cunha e Cruz, para escrever este editorial especial de aniversário. Todos nós da Comissão Editorial desejamos a leitores, autoras, avaliadores e editores da EJJL que 2021 entregue o que esperamos dele: que a ciência seja mais importante em nossas vidas. E que a ciência publicada nos ajude a tomar as decisões complexas que teremos pela frente.

Comemoramos os 20 anos da EJJL com alegria. Comemore conosco.

Prof. Dr. Carlos Luiz Strapazzon, 7 de dezembro de 2020. 
